Jurnal Pendidikan Akuntansi Indonesia, Vol. IX. No. 1 - Tahun 2011, Hlm. 83 - 89

\title{
TINGKAT MANAJERIAL DAN PENGELOLAAN KEUANGAN USAHA MIKRO, KECIL DAN MENENGAH (UMKM) DI KAB. KULONPROGO
}

\section{Oleh : \\ Siswanto ${ }^{1}$}

\begin{abstract}
ABSTRAK
Penelitian ini bertujuan untuk mengetahui:(1)manajerial yang dilakukan UMKUdi Kab.Kulonprogo;(2)Pengelolaan Administrasi UMKM di Kab. Kulonprogo;(3) Pengelolaan Keuangan UMKM di Kab. Kulonprogo.

Subjek penelitian ini adalah UMKM bidang keuangan, jasa dan koperasi di Ka. Kulonprogo dengan populasi 532 dan diambil sampel 95. Pengambilan sampel dengan Purposive Random sampling. Penelitian ini menggunakan pendekatan ex post facto, karena peneitian ini hanya mengungkapkan fakta saja yang telah terjadi tanpa ada manipulasi variabel atau menciptakan kondisi tertentu. Dilihat dari sifatnya penelitian termasuk penelitian Diskriptif kuantitatif.Metode pengumpulan data dengan menggunakan kuesioner tertutup.Data yang diperoleh di analisis dengan pendekatan diskriptif kuantitatif, analisis ini digunakan untuk memgambarkan Tingkat manajerial, administrasi dan keuangan UMKM di Kab. Kulonprogo cara mengambarkan dalamtabel kecenderungan dengan kriteria yang telah ditentukan.

Hasil Penelitian Menunjukkan:(1)tingkat pengelolaan manajerial UMKM Kab. Kulonprogo secara umum masih tergolong lebih dari cukup baik $(63 \%)$ memiliki kategori Cukup baik, baik dan sangat baik, dan 37\% yang berkategori kurang baik;(2)tingkat pengelolaan Administrasi UMKM Kab. Kulonprogo memiliki kecenderungan Kurang Baik (57\%),hanya 43\% yang memiliki kategori Cukup baik, baik dan sangat baik;(3)tingkat pengelolaan Keuangan UMKM Kab. Kulonprogo memiliki kecenderungan Kurang Baik (54\%), hanya 46\% yang memiliki kategori cukup baik, baik dan sangat baik.
\end{abstract}

Kata Kunci : Manajerial, Pengelolaan Keuangan, UMKM

\begin{abstract}
PENDAHULUAN
Potensikewirausahaanuntukdapatmeningkatkankesejahteraanhidupsebenarnyat elahadapadasetiap orang, untukmenjadipengusaha yangmandiriperluadanyapelatihanmanajemenusahadaripihakpihakterkait.Misalnyaperluadanyapengembanganjiwakewirausahaansertapengelolaanu sahabagipihak-pihak yang mempunyaipotensi.Padakenyataanyabanyakkegiatanusaha yang dilakukanbelumterencanadengancermatdenganmemperhatikanresiko yang mungkinterjadisertakeberlanjutanusahakedepan, pengusahakecildanmenengah.

KeberadaanKampus UNY Watesoleh PEMDA KulonprogodiharapkandapatmembangkanEkonomiKulonprogo, sebagaibentuk rasa kepeduliankampusdankerjasamadengan PEMDA KulonProgosudahsewajarnya UNY
\end{abstract}

\footnotetext{
${ }^{1}$ Dosen Jurusan Pendidikan Akuntansi - Universitas Negeri Yogyakarta
} 
Watesmemperhatikanperkembanganusaha yang dilakukanolehwargasekitarkampus. Dengankepedulian yang senantiasaditunjukkanolehkampusakanmenciptakansuasana yang harmonisantarakampusdanwargasekitarsertahubungan yang Baikdengan PEMDA KulonProgo. Pengelolaan Usaha yang dilakukanPelakuusaha di selamainiterlihatkurangbegituTertatakarenaseringbukadantutupdanbergantiusaha yang dilakukankarenamengalamikerugianataupunkurangdiminatiataubahkankalahbersaingd enganpengusaha yang lebihbesar.

Kemampuandalampengelolaanusaha mendasarbelumdimilikiolehparapelaku Usaha yaituManajerialusaha, AdministrasiumumdanKeuangansertapenyusunanLaporanKeuangan.BeberapaMasala hitusebenarnya yang akanmempengaruhikeberhasilanusaha yang dilakukan, denganadanyaManajerial yang bagusdiharapkanpengelolaan yang dilakukansenantiasamemperhatikanaspek-aspekpengembangan yang seharusnya. SelanjutnyaAdministrasidokumen-dokumenkeuangandanumum yang digunakandalampelaksanaanusahasangatmendukungdalammenjalankanusahasertapen gelolaan yang profesional.PenyusunanLaporanKeuangan yang sesuaidengankaidah yang bakusangatmenunjangkepercayaanmasyarakatdanPemerintahuntukmemperluasdanme ngembangkanusaha.UMKM

KulonprosaatinibelumdiketahuibagaimanatingkatManejerialsertapengelolaankeuanga $\mathrm{n}$ yang dilakukan, sehingga program pengembangantidaktepatsasaran.DalamrangkamembantuPemdaKulonprograuntukmer encanakan Program makaperluadanyapemetaanterkaitmanajerialsertapengelolaankeuangan UMKM di kulonprogro.

Denganmemahamipermasalahan yang adamaka UNY KampusWatesberencanaakanmengadakanPenelitian Tingkat ManajerialdanpengelolaanKeuangan UKM di Kab. Kulonprogo.Pengelolaan yang dimaksudadalamterkaitdeganManajerial,

AdminstrasiUmumdanKeuangansertaPenyusunanLaporanKeuanganbagiPengelolaan Usaha.

\section{PerumusanMasalah}

Berdasarkanpermasalahan yang telahdituangkandalamanalisissituasi di atasmakadapatdirumuskanpermasalahansebagaiberikut:

1. BagaimanaKegiatan Usaha UMKM di kab. Kulonprogo.

2. BagaimanakondisiMenajerial UMKM di Kab. Kulonprogo .

3. Bagaimana Pengelolaan Keuangan UMKM di Kab. Kulonprogo.

\section{TujuanPenelitian}

PenelitianiniBertujuanuntuk :

1. Melakukan Pemetaan Usaha yang dilakukan UMKM di Kab. Kulonprogo.

2. Mengetahui Tingkat Manajerial yang dilakukan UMKU di Kab.Kulonprogo.

3. Mengetahui Tingkat Pengelolaan Keuangan UMKM di Kab. Kulonprogo.

\section{KAJIANPUSTAKA}

Suparman Sumahamidjaya (1981.157) memberi batasan kewirausahaanadalah orang yang melakLlkan kegiatan mengorganisasikan faktor-faktor produksi danmemberikan hasil yang produktif Hal tersebut tampaknya sarna dengan pendapatShumpeter, yang dikutip oleh Buchari Alma (1999.12) bahwa Kewirausahaan adalah orang yang unik berpembawaan, pengambil resiko, 
memperkenalkan produk-produk inovatif dan teknologi baru ke dalam perekonomian.Pendapat tersebut di atas di samping menekankan pada produktivitas Shumpeter menambah unsur lain yakni unsur pengambil resiko, hal tersebut sejalan rlengan pendapat Savary (1973) yang dikutip oleh Soehardi Sigit (1980:1) Kewirausahaan adalah membeli barang dengan harga pasti, meskipun orang itu belum tahu dengan harga berapakah barang (atau guna ekonomi) itu akan dijual kemudian.Yean Baptist Say yang dikutip oleh Buchari Alma (1999:13) yang pada dasarnya kewirausahaan mengarah kepada keberhasilan dalam menggabungkan antaraproduksi, perlengkapan manajemen yang kontinyu sebagai penanggung resiko.

Berhasil tidaknya suatu bangsa dalam melaksanakan pembangunan tergantung kepada penduduknya yang mempunyai motif untuk berhasil. Demikian juga berdasarkan pendapat David Osbourne dan Ted Gaebble (1992) dalam bukunya yangberjudul Reivelling Government yang berarti mewirausahakan birokrasi yang dikutipoleh Buchari Alma (1999: 5) kaitannya dengan keberhasilan merupakan kebutuhan yang baku yang ada di dalam diri setiap manusia (need of achievement) maka kewirausahaan mempunyai arti yang luas tidak hanya pada sektor produksi resiko namun kewirausahaan sangat berhubungan dengan keberhasi Ian scbab kewirausahaan sangat diperlukan oleh setiap :individu jika kita lihat bagaimana arti dan definisi semulanva. lebih-Iebih jika kewirausallaan dilihat dari fungsinya bagi kehidupan

Wirausaha mempunyai kekuatan mental yangtinggi sehingga memungkinkan ia melompat dan meluncur maju ke depan di luarkemampuan rata-rata, bahkan ada kalanya wiraswastawan tidak harus berpendidikantinggi, namun akan lebih baik mutu wiraslvastawan jika ia berpendidikan tinggiSeclangkan menurut Daoedyoesoef sebagaimana dikutif oleh Buchari Alma.(1999: 5) wirausaha adalah orang yang memimpin usaha baik secara teknis dan atau ekonomis dengan berbagai aspek fungsinya dan memburu keuntungan/manfaat secaramaksimal dengan usaha kearah kemajuan, perluasan perkembangan melaluijalan kepemimpinan ekonomi elemi berbagai kepentingan.Pendapat tersebut diatas tampaknya tidak jauh berbeda dengan pendapat Haryati Subadio. yang dikutip oleh Buchari Alma (1999 : 8) yang menyatakan balwa wirausaha adalah manusia teladan. berbudi luhur dalam arti manusia yang mampuberdiri atas kemampuan sendiri. tidak saja di sektor swasta tapi juga dalam sektornegaraPendapat tersebut diatas diperkuat oleh Sudjoko (19998) menyatakan bahwa wiraswasta adalah mereka yang memiliki nilai-nilai manusia perintis, pejuang kemerdekaan, kemajuan dan nilai kepribadian

\section{CARA PENELITIAN}

Penelitianinimenggunakanpendekatanex

post

facto, karenapeneitianinihanyamengungkapkanfaktasaja yang telahterjaditanpaadamanipulasivariabelataumenciptakankondisitertentu.

Dilihatdarisifatnyapenelitiantermasukpenelitiandiskriptifkuantitatif, karenapenelitianninibertujuanmengambarkansuatukeadaan adadenganmenggunakan data-data yang angkasertapenafsirannyaberdasarkan parameter yang berlaku.

Metodepengumpulan data denganmenggunakanKuesioner, metodeinimengunakandaftarpertanyaan yang telahdisusundandisiapkansedemikianrupasehinggarespondentinggalmengisiataumenan daidenganmudahdancepat, Kuesioner yang digunakandalamevaluasiiniadalahclosed ended questionerataukuesionertertutupyaituberbagaipertanyaan yang 
dibuatdenganmemberikanalternatifjawaban

yang

telahtersedia, sehinggarespondentinggalmemilihjawaban yang adasesuaikondisi yang sebenarnya. Metodeinidigunakanuntukmengetahuiberbagaikompentensicalon guru yang telahdimilikiolehmahasiswa

Data yang diperolehakan di analisisdenganpendekatandiskriptif, analisisinidigunakanuntukmemgambarkanTingkat

ManajerialdanPengelolaanKeuangan UMKM,

dilakukandenganmengunakantabelkecenderungandenganstrandar

telahditentukansebagaiberikut :

\begin{tabular}{|l|l|c|}
\hline No & \multicolumn{1}{|c|}{ Formula } & Kategori \\
\hline 1 & $\mathrm{X}>\left(\mathrm{M}_{\mathrm{i}}+1 . \mathrm{SD}_{\mathrm{i}}\right)$ & SangatBaik \\
\hline 2 & $\left(\mathrm{M}_{\mathrm{i}}+1 . \mathrm{SD}_{\mathrm{i}}\right) \geq \mathrm{X} \geq \mathrm{M}_{\mathrm{i}}$ & Baik \\
\hline 3 & $\mathrm{M}_{\mathrm{i}}>\mathrm{X} \geq\left(\mathrm{M}_{\mathrm{i}}-1 . \mathrm{SD}_{\mathrm{i}}\right)$ & CukupBaik \\
\hline 4 & $\mathrm{X}<\left(\mathrm{M}_{\mathrm{i}}-1 . \mathrm{SD}_{\mathrm{i}}\right)$ & KurangBaik \\
\hline
\end{tabular}

Keterangan $: \mathrm{X}=$ jumlah skor mahasiswa, $\mathrm{M}_{\mathrm{i}}=$ rerata ideal,

$\mathrm{SD}_{\mathrm{i}}=$ simpangan baku ideal,

\section{HASIL PENELITIAN DAN PEMBAHASAN}

1. Tingkat Manajerial UMKM Kab. Kulonprogo

Berdasarkan hasil pengolahan instrument penelitian dan mengacu pada kategorisasi yang telah ditentukan, maka dapat disusun kategori Tingkat manajerial UMKM Kab. Kulonprogo .

Tabel 1. Hasil Kategori Manajerial UMKM Kab. Kulonprogo.

\begin{tabular}{|c|c|c|c|}
\hline \multirow{2}{*}{ No } & \multicolumn{2}{|c|}{ Frekuensi } & \multirow{2}{*}{ Kategori } \\
\cline { 2 - 3 } & Absolut & Relatif \% & \\
\hline 1 & 24 & 24 & SangatBaik \\
\hline 2 & 12 & 14 & Baik \\
\hline 3 & 25 & 26 & CukupBaik \\
\hline 4 & 34 & 36 & KurangBaik \\
\hline
\end{tabular}

Dari Tabel 1 di atasmenunjukkankategoriManajerial UMKM Ka.Kulonprogoadalah ; SangatBaik24\%; Baik14\%; CukupBaik26\%; danKurangBaik36\%, sehinggadapatdiketahuitingkatkecenderunganManajerial UMKM di kab. KulonprogoadahahKurangBaik.Hal initerlihatdarihasilpengolahan data kecenderunganmenunjukkansebagianrespondenberadapadakategoriKurangBaik (36\%).Sedangkanpelaku UMKM memilikimanajerialCukupataulebihbaikmencapai yang 63\%.Dengandemikiandapatdisimpulkanwalaupunsebagianbesar UMKM padakategori yang kurangbaiknamum UMKM yang telahmemilikitingkatmanajerial yang cukupdanlebihdaribaikadalahlebihbesar $(63 \%)$.

2. Tingkat Pengelolaan Adminisrasi UMKM Kab. Kulonprogo

Berdasarkanhasilpengolahan instrument penelitiandanmengacupadakategorisasi yangtelahditentukan, makadapatdisusunkategori Tingkat PengelolaanAdminisrasi UMKM Kab. Kulonprogo .

Tabel 1.HasilKategoriPengelolaanAdminisrasi UMKM Kab.Kulonprogo.

\begin{tabular}{|l|l|l|}
\hline No & Frekuensi & Kategori \\
\hline
\end{tabular}




\begin{tabular}{|c|c|c|c|}
\hline & Absolut & Relatif $\%$ & \\
\hline 1 & 22 & 23 & SangatBaik \\
\hline 2 & 13 & 13 & Baik \\
\hline 3 & 7 & 7 & CukupBaik \\
\hline 4 & 54 & 57 & KurangBaik \\
\hline
\end{tabular}

Dari Tabel 1 di atas menunjukkan kategori Pengelolaan Adminisrasi UMKM Ka. Kulonprogo adalah ; Sangat Baik 23\%; Baik 13\%; Cukup Baik 7\%; dan Kurang Baik $57 \%$, sehingga dapat diketahui tingkat kecenderungan Pengelolaan Adminisrasi UMKM di kab. Kulonprogo adahah Kurang Baik. Hal ini terlihat dari hasil pengolahan data kecenderungan menunjukkan sebagian responden berada pada kategori Kurang Baik (57\%). Sedangkan pelaku UMKM yang memiliki manajerial Cukup atau lebih baik mencapai 43\%. Dengan demikian dapat disimpulkan walaupun sebagian besar UMKM pada kategori yang kurang baik namum UMKM yang telah memiliki tingkat pengelolaan Admistrasi yang cukup dan lebih dari baik adalah lebih besar $(43 \%)$.

2. Tingkat Pengelolaan Keuangan UMKM Kab. Kulonprogo

Berdasarkan hasil pengolahan instrument penelitian dan mengacu pada kategorisasi yang telah ditentukan, maka dapat disusun kategori Tingkat Pengelolaan Keuangan UMKM Kab. Kulonprogo .

Tabel 1. Hasil Kategori Pengelolaan Keuangan UMKM Kab. Kulonprogo.

\begin{tabular}{|c|c|c|c|}
\hline \multirow{2}{*}{ No } & \multicolumn{2}{|c|}{ Frekuensi } & \multirow{2}{*}{ Kategori } \\
\cline { 2 - 3 } & Absolut & Relatif $\%$ & \\
\hline 1 & 18 & 19 & SangatBaik \\
\hline 2 & 8 & 9 & Baik \\
\hline 3 & 16 & 18 & CukupBaik \\
\hline 4 & 51 & 54 & KurangBaik \\
\hline
\end{tabular}

Dari Tabel 1 di atas menunjukkan kategori Pengelolaan Adminisrasi UMKM Ka. Kulonprogo adalah ; Sangat Baik 19\%; Baik 9\%; Cukup Baik 18\%; dan Kurang Baik $54 \%$, sehingga dapat diketahui tingkat kecenderungan Pengelolaan Keuangan UMKM di kab. Kulonprogo adahah Kurang Baik. Hal ini terlihat dari hasil pengolahan data kecenderungan menunjukkan sebagian responden berada pada kategori Kurang Baik (54\%). Sedangkan pelaku UMKM yang memiliki Pengelolaan Keuangan Cukup atau lebih baik mencapai 46\%. Dengan demikian dapat disimpulkan walaupun sebagian besar UMKM pada kategori yang kurang baik namum UMKM yang telah memiliki tingkat manajerial yang cukup dan lebih dari baik adalah lebih besar (46\%).

Dari hasil penelitian menunjukkan bahwa tingkat manajerial UMKM di Kab. Kulonprogo menunjukkan kategori yang kurang baik, dari 95 responden yang berhasil di peroleh data terdapat 34(36\%) menunjukkan kurang baiknya pengelolaan manajerial mereka. Pengelolaan manajerial yang dimaksud adalah terkait penyusunan Program kerja (Busines Plan) secara periodik, menentukan target kerja, melakukan evaluasi kerja, pembagian tugas, pemantauan kegiatan bisnis, penyusunan laporan hasil kerja, menjalin kerjasama dengan pihak luar baik pemerintah maupun swasta. Dari berbagai indikator yang disusun menunjukkan bahwa hanya $24 \%$ yang melakukan kegiatan manajerial dengan sangat baik, 14\% melaksanakan dengan baik serta 26\% melakukan dengan cukup baik. Namum secara keseluruhan dapat diketahui 
bahwa UMKM di Kab. Kulonprogo yang telah menyelenggaranan pengelolaan manajerial dengan cukup baik atau lebih telah mencapai $63 \%$.

Tingkat pengelolaan Administrasi UMKM di Kab. Kulonprogo menunjukkan kategori yang kurang baik, dari 95 responden yang berhasil di peroleh data terdapat 54(57\%) menunjukkan kurang baiknya pengelolaan Administrasi mereka. Pengelolaan Administrasi yang dimaksud adalah terkait tersedianya admnistrasi umum persuratan (logo,nama, alamat) pada kegiatan korespondensi, pebuatan surat resmi pada setiap kegiatan bisnis, pembuatan surat sesuai dengan kaidah korespondensi dan bahasa, pengarsipan surat masuk dan keluar secara tertip dan benar, pengarsipan dokumen bisnis dengan baik, memiliki dokumen yang mendukung administrasi (ijin usaha, NPWP, Ijin gangguan dll). Dari berbagai indikator yang disusun menunjukkan bahwa hanya $23 \%$ yang melakukan kegiatan manajerial dengan sangat baik, $13 \%$ melaksanakan dengan baik serta $7 \%$ melakukan dengan cukup baik. Namum secara keseluruhan dapat diketahui bahwa UMKM di Kab. Kulonprogo yang telah menyelenggaranan pengelolaan Administrasi dengan cukup baik atau lebih telah mencapai $43 \%$.

Dari hasil penelitian menunjukkan bahwa tingkat pengelolaan Keuangan UMKM di Kab. Kulonprogo menunjukkan kategori yang kurang baik, dari 95 responden yang berhasil di peroleh data terdapat 51(54\%) menunjukkan kurang baiknya pengelolaan keuangan mereka. Pengelolaan keuangan yang dimaksud adalah terkait dengan penyusunan anggaran dan belanja perusahaan setiap awal periode, pencatatan setiap transaksi bisnis perusahaan, memiliki bukti transaksi untuk setiap kegiatan bisnis, menyusun catatan keuangan (jurnal, buku besar, buku pembantu dll), menyusun Laporan keuangan (Neraca,Laporan Laba/Rugi, Lap perubahan Modal dan Arus Kas serta memberikan Laporan perkembangan usaha kepada pihak yang terkait (pemerintah, investor dan pemilik). Dari berbagai indikator yang disusun menunjukkan bahwa hanya $23 \%$ yang melakukan kegiatan manajerial dengan sangat baik, $13 \%$ melaksanakan dengan baik serta 7\% melakukan dengan cukup baik. Namum secara keseluruhan dapat diketahui bahwa UMKM di Kab. Kulonprogo yang telah menyelenggaranan pengelolaan Administrasi dengan cukup baik atau lebih telah mencapai $46 \%$.

\section{KESIMPULAN}

Dari Hasil penelitian serta pembahasan dapat diambil Kesimpulan sebagai berikut :

1. Tingkat pengelolaan manajerial UMKM Kab. Kulonprogo secara umum masih tergolong lebih dari cukup baik (63\%) memiliki kategori Cukup bai, baik dan sangat baik, dan $37 \%$ yang berkategori kurang baik. .

2. Tingkat pengelolaan Administrasi UMKM Ka. Kulonprogo memiliki kecenderungan Kurang Baik (57\%),hanya 43\% yang memiliki kategori Cukup baik, baik dan sangat baik. .

3. Tigkat pengelolaan Keuangan UMKM Kab. Kulonprogo memiliki kecenderungan Kurang Baik (54\%), hanya 46\% yang memiliki kategori cukup baik, baik dan sangat baik.

\section{DAFTAR PUSTAKA}

Anonimous, (2003). Grand Strategi Pengembangan Sentra UKM. Kementrian Koperasi dan UKM RI, Jakarta

Ign.Sukamdiyo (1996) Manajemen Koperasi,Erlangga,Jakarta. 
Tambunan, Tulus (2008), "Prospek Perkembangan Koperasi di Indonesia ke depan: Masih Relevankah Koperasi di dalam Era Modernisasi Ekonomi”, Penelitian Dosen, Juni, Fakultas Ekonomi, Universitas Trisakti.

Sumarsono, Sonny (2003), Manajemen Koperasi. Teori dan Praktek, Jakarta: Graha Ilmu.

Revrisond Baswir(1997), Agenda Ekonomi Kerakyatan, Pustaka Pelajar, Jogjakarta 